\title{
Living with the Dead: Contested Spaces and the Right to Cairo's Inner City Cemeteries
}

\author{
Wael Salah Fahmi ${ }^{1, *}$, Keith Sutton ${ }^{2}$ \\ ${ }^{1}$ Department of Architecture, University of Helwan, 34, Abdel Hamid Lofti Street, Giza, 12311, \\ Egypt; E-Mail: uders2004@yahoo.co.uk \\ ${ }^{2}$ School of Environment and Development, University of Manchester, Oxford Road, Manchester, M13 \\ 9PL, UK; E-Mail: ksysutton@tiscali.co.uk, k.sutton@manchester.ac.uk \\ * Author to whom correspondence should be addressed; E-Mail: uders2004@yahoo.co.uk; Tel.: +2 02 \\ 33370485 ; Fax: + 2- 02- 33351630
}

Received: 10 September 2014 / Accepted: 31 October 2014 / Published: 1 November 2014

\begin{abstract}
Cairo's spontaneous poor communities signify the growing socio-economic disparity since 1970s open door economic liberalisation policy and 1990s IMF's structural adjustment program. These poverty belts attract rural migrants and urban poor from Cairo's residential core areas as a result of high land prices, shortage of affordable housing and decay of existing housing stock . Typical example of these poverty belts are cemetery areas (Cities of the Dead ) within Cairo's eastern fringes. The aim of the article is to examine contested spaces within the Cities of the Dead, initially through a reconsideration of the number of occupants and of the relative balance of tomb dwellings and more conventional shantytown buildings. The tombs and mausoleums of the city's ancient and extensive cemeteries have been occupied by squatters, some of whom live in the mausoleums themselves, others in self-built constructions between and around the tombs.
\end{abstract}

The paper raises several questions such as :

- Does lack of affordability to provide an alternative residence play a key role in the occupation by people of tombs (hawch) by people in these cemeteries? Is there any possibility of classifying tomb 
dwellers into social groupings with various job types, income levels, educational status as well as residence patterns?

- Does living in tombs generate a new value system, cultural patterns and social behaviour? Can one consider cemeteries as an isolated marginal area within Cairo's society?

The current study is organised into three main sections. The first of which focuses on the general background of the Cities of the Dead in central Cairo looking at the socio-demographic and economic conditions characterising various cemetery areas with an emphasis on reasons behind living in cemeteries. Then the uniqueness of these Cairo squatter settlements is challenged through a range of socio-economic data which demonstrate the way their supposedly marginalised occupants are in part integrated into the city's urban economy. A comparative study is made of various household characteristics based on secondary data from official reports and academic research. These results will further relate to both small area survey and 1996 population census data concerning age structure, marital status, educational levels, jobs, access to the CBD and the inner city, income level, residence, social relationships and formal and informal services. The second part of the study sets out to examine socio-economic problems in the area generally and more specifically relating to the hawch cemetery people. The latter can be regarded as an example of squatter settlements together with those people living in the residential 'islands' or in-fillings (gozor) which resemble more conventional spontaneous or informal squatter areas elsewhere in Cairo.

Inter- generational perception of future prospects and expectations will be investigated within focus group discussion with people's responses and coping strategies being examined. This provides the basis against which the third section of the study will explore the scenarios and alternatives with differentiation being made between people living in tombs (hawch) and those in residential islands (gozor) and surrounding spontaneous settlements such as Manshiet Nasser. In this section the empirical small area survey examines the northern cemeteries' tomb dwellers' right to the city and their resistance against official eviction plans .Such relocation policy is attributed to the fact that the Cities of the Dead provide urban investment opportunities as a result of good road accessibility and geographical propinquity to Medieval Cairo's historical quarters and its ongoing tourist-orientated urban gentrification projects. Behind the declared official justification for eviction proposals of tomb dwellers, to Greater Cairo's suburban eastern desert, in terms of improving the environment and creating sustainable settlements, there lies a wider but hidden agenda. The local municipality aims to clear such strategically central areas from the presence of the poor, with legislation to protect the environment as a justification for securing access to land for urban gentrification projects.

The paper emphasises the significance of poverty alleviation initiatives in strengthening urban poor's capacity to negotiate with local authorities for security of land tenure and legal recognition of their spontaneous settlements. The study proposes a stakeholder approach to the sustainable development of inner city poverty areas, whilst advocating radical policy action and collaborative planning for consolidating bottom up urban governance. Partnership between community based groups, grass root organisations, local authorities and planners would support urban poor's sustainable initiatives to improve their housing standards and basic services.

Key words: Cairo - cemeteries-tomb dwellers- eviction-gentrification-spatial contestation 


\section{Introduction}

Cairo's Cities of the Dead squatter settlements occupy a significant place in the literature on both Cairo and on squatter and informal settlements. This stems from their reputed size in terms of number of people living there, allegedly over one million, and from their apparent uniqueness with squatter families occupying the tombs or hawch. The aim of the article is to reassess and demystify the Cities of the Dead, initially through a reconsideration of the number of occupants and of the relative balance of tomb dwellings and more conventional shanty town buildings. Then the uniqueness of these Cairo squatter settlements is challenged through a range of socio-economic data which demonstrate the way their supposedly marginalised occupants are in part integrated into the city's urban economy. The pioneering 1980s research of El Kadi [1,2] first intimated that this squatter society bore comparison with squatter settlements elsewhere in the Third World. More recent 1990s data, especially that produced by the General Organisation for Physical Planning GOPP [3] and by the National Population Council (NPC) [4], focuses particularly on the minority tomb dwellers within the Cities of the Dead and corroborates El Kadi's findings. On the basis of material presented from these sources it is argued in this study that the more general literature on squatter settlements and on the informal economy is as applicable to Cairo's Cities of the Dead as to other Third World cities [5]. Finally the article focuses on the various scenarios put forward by planners and others for the Cities of the Dead in the future as an integral part of Greater Cairo. The overall aim is to demonstrate that the apparent uniqueness of the Cities of the Dead obscures their comparability with squatter settlements elsewhere. As Shorter observed "the exotic quality of their settlement has directed more attention to them than is quantitatively warranted."[6] However the attitudes and perception of both tomb (hawch) dwellers and Cairene people in general have played a significant role in giving the City of the Dead's population a more marginalised status within Cairo's urban poor.

Cairo's 'Cities of the Dead' have entered the Third World settlement literature as a unique kind of squatter settlement. The tombs and mausoleums of the city's ancient and extensive cemeteries have been occupied by squatters, some of whom live in the mausoleums themselves, others in self-built constructions between and around the tombs. Estimates of the numbers of people involved have varied wildly, though recent studies by El Kadi [1], the NPC [4] and others have permitted more accurate and realistic evaluations to be made. These studies have also corrected earlier misconceptions about the squatters through socio-economic surveys of the squatter families. This growing body of more accurate information on the people inhabiting the Cities of the Dead makes a significant contribution now to appreciating the importance and role of these old cemetery areas in the wider built environment of Greater Cairo. Their present and possible future roles can be better assessed and future scenarios for this unique district can be suggested.

The first section of the article focuses on the socio-demographic and economic conditions characterising the City of the Dead. This section analyses existing conditions and problems of rural migration, over-population and housing shortage, unemployment and deteriorated lifestyle amongst cemetery people. A comparative study is made of various household characteristics based on studies by the NPC [4] which sampled 1500 households from 17 cemeteries, by El Kadi [2], by Gad [7] sampling 300 households in El-Imam El-Shafei' and the Eastern Cemetery, by El Kordy [8] looking at 1000 households in El-Sayeda Nafeissa, El-Imam El- Shafei', El-Mogawerien and El-Ghafeir cemeteries, including with 150 intensive case studies, by El Faramawy [9], and by the GOPP [3] which focused on the Eastern Cemetery with a 918 house sample survey in El-Mogawerien, El-Ghafeir, Ezbet El-Barquoky and El-Muslimein cemeteries. These results will relate to both small area survey within Bab El-Nasr northern cemeteries and 1996 socio-demographic and economic census. The second part of the study examines the socio-economic problems in the area, mainly in relation to tomb 
dwellers and those people living in residential 'islands' or in-fillings (gozor). The third section of the study will explore future scenarios and alternatives within focus group discussion, in relation to the partial removal of Bab El-Nasr northern cemeteries and the situation within the City of the Dead since the 2011 uprising .

More specifically we propose in this article that hawch people do not necessarily display specific distinctive characteristics which are all that different from Cairo's urban poor with respect to demographic, social and economic traits. However the rest of the city's people do possess a negative image of cemetery people and this perception together with planner's future scenarios for the area have contributed to the further marginalisation of the tomb dwellers [5].

\section{The Location and Origins of the Cemeteries and their Residents}

There are two main cemetery areas involved, the Southern Cemetery and the Eastern (also known as the Northern) Cemetery. They lie south and east of the old Fatimid or pre-nineteenth century medina area of the city, often known as Old Cairo (Figure 1). The cemeteries occupy much of the area between Old Cairo and the distinctive Muqattam Plateau. A third and somewhat different City of the Dead is the smaller Bab El-Nasr cemetery to the north of Old Cairo which is distinctive in terms of its wooden mausoleums and its inclusion in the recent North El-Gamaliya planned rehabilitation programme. Alternatively this cemetery can be considered as part of the Eastern Cemetery, extending from South to North (Figure 2) with Bab El-Wazeir, El-Mogawerien, the Eastern Muslims Cemetery and Qaytbay. The Cemetery is accessed from the North through Salah Salem Street and the Autostrada (except for the Bab El-Nasr and Bab El-Wazeir sections). To the east of the cemetery lies the spontaneous quarter of Manshiet Nasser and the Muqattam Plateau which separate the area from the Southern Cemetery. The latter is the largest agglomeration of tombs including from south to north, the El-Bassatine, ElTounsi, El-Imam El-Shafei', Ibn El-FadI, El-Mamaleik, and El-Sayeda Nafeissa cemeteries. To its east is the Muqattam Plateau and to the west the plain of Ein El-Seira while to the south is vacant land. 
Figure 1. Location of the Cities of the Dead: The Eastern Cemetery and the Southern Cemetery

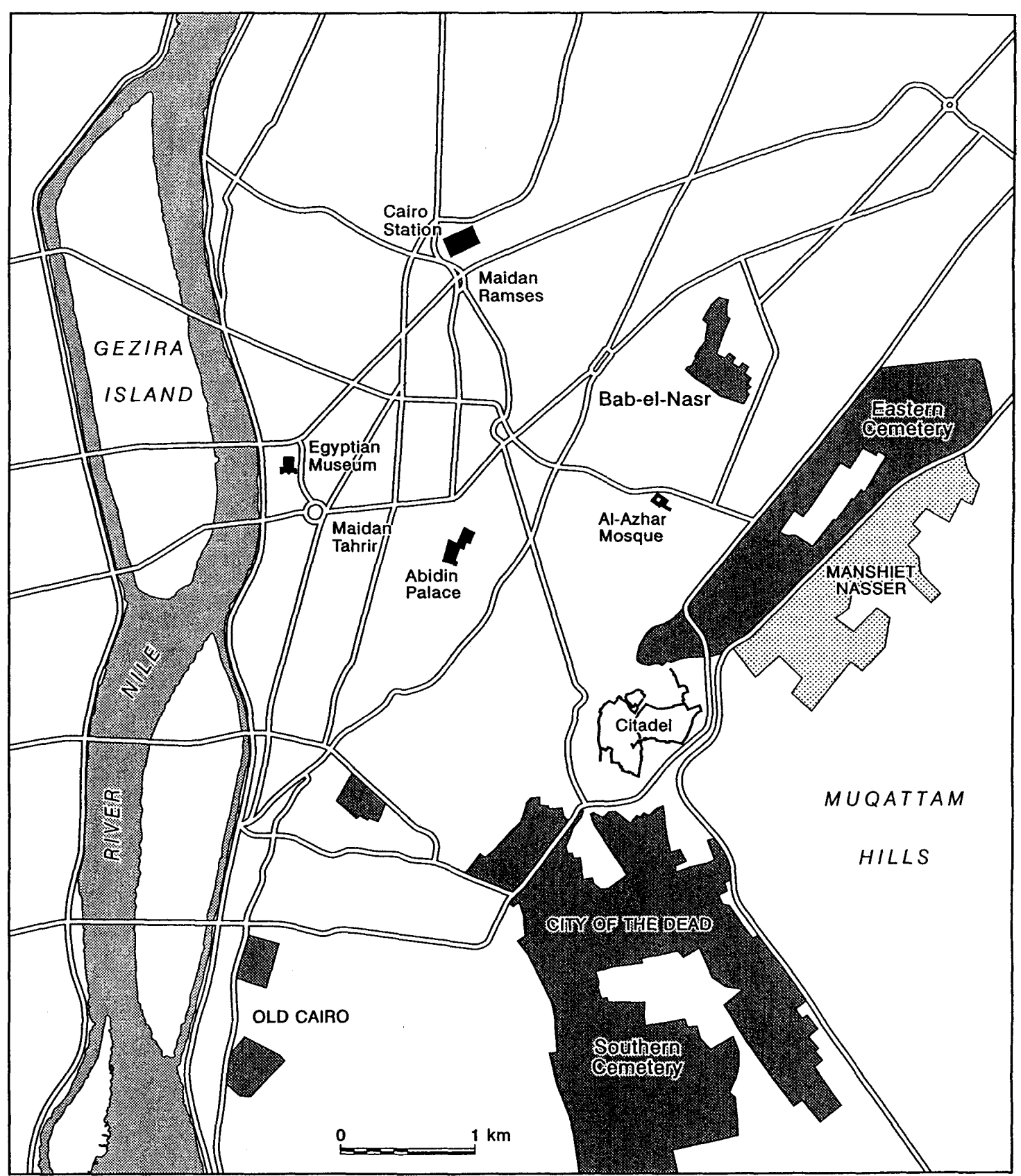

Source: GeoCenter,World City, Cairo, 1:15 000. Germany 
Figure 2. Individual cemeteries within the Cities of the Dead

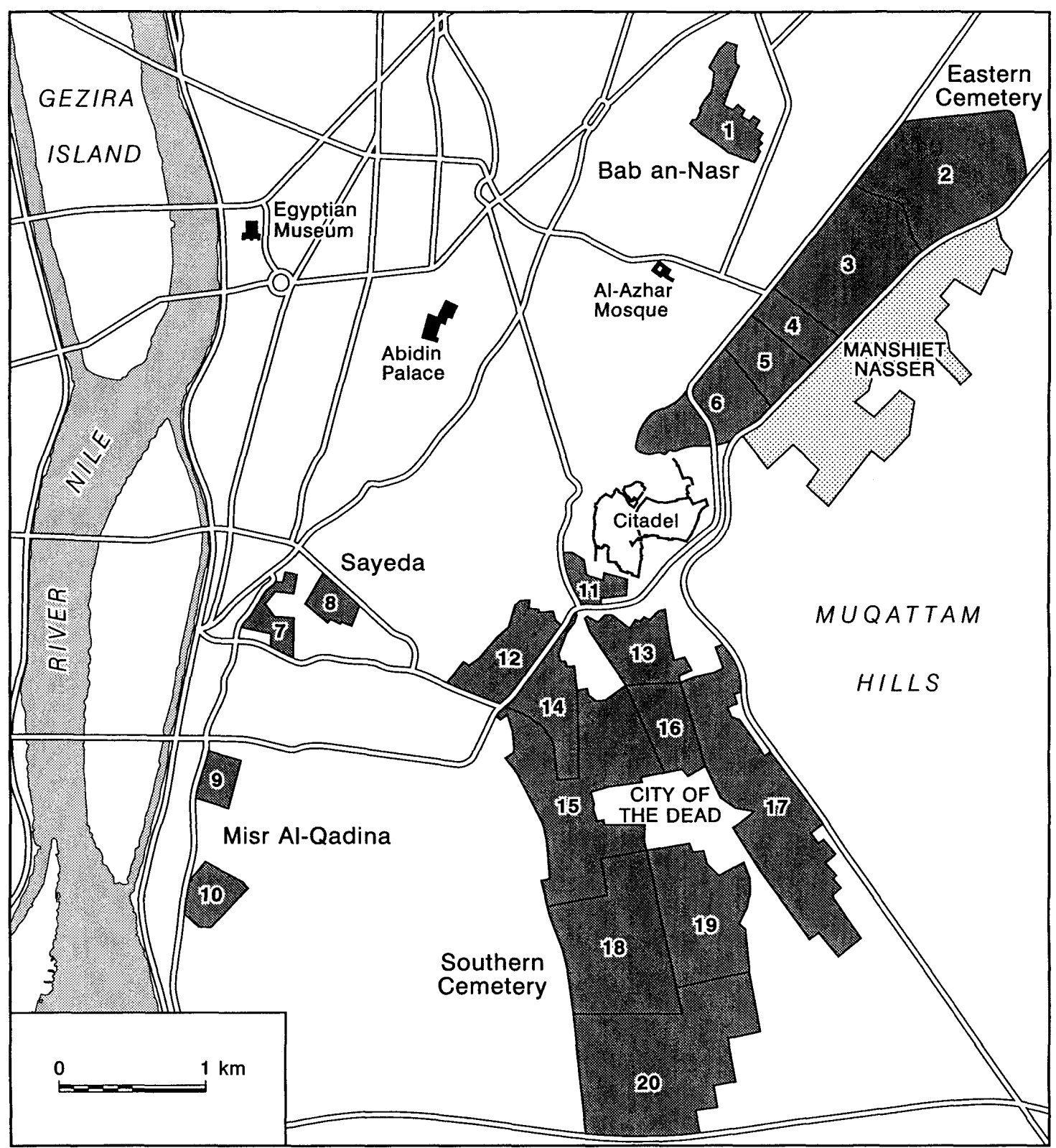

\section{Source: GOPP [3]}

Key: List of Cemeteries ( 1 acre equals 0.4046 hectares)

1. Bab El-Nasr (25 acres)

2. El-Ghafeir (45 acres)

3. Qaytbay (45 acres)

4. El-Sharkia El-Muslimein (18 acres)

5. El-Mogawerein (32.5 acres)

6. Bab El-Wazeir (18.75 acres)

7. Ard El-Orthothox (15 acres)

8. Zein El-Abidin (7.28 acres)

9.Amr Ibn El-A'as (7 acres)

10. El-Imam El- Shafei' (5 acres)
11.Arab El-Yassar (7.5 acres)

12. El-Sayeda Nafeissa (21acres)

16. Omar Ibn El-Fard (15 acres)

13. El-Mamaleik (20 acres)

14. El-Kadreyah (20 acres)

15.Arab Qureish (6 acres)

17. El-Abagiya / SidiYeheya Abu

El-Wafa / El-Sadat / Sidi El-Shateby (42 acres)

18. El-Imam El-Leithy (49 acres)

19. El-Tounsi (28 acres)

20. El-Bassatine (84 acres)

21. Coptic and Orthodox Cemetery 
The main focus of this study will be the Eastern Cemetery (Figures 3, 4) including El-Mogawerien, ElGhafeir, Ezbet El-Barquoky, and El-Muslimein cemeteries. The survey will cover land use patterns, building heights, conditions, public facilities, patrimony and type of ownership, type of occupancy, architectural style and urban fabric. The cemetery function of these districts, especially of the Southern Cemetery, dates back to early Medieval, and decidedly pre-Fatimid (960-1171 A.D.) times, when Old Cairo's precursors, the cities of Fustat and Misr, developed the land between their built-up area and the Muqattam Hills as a burial ground. Abu-Lughod remarks on the strange paradox that "while the city of the living at Fustat has long since disappeared, its city of the dead - much expanded - continues to house thousands of residents of the contemporary city."[10]

As well as basic tombs and mausoleums, both the Southern and Eastern cemeteries contain many impressive Islamic monuments, mosques, splendid domed tombs of significant historic individuals, and other religious and funerary buildings, especially from the Mamelouk period (1250-1570 A.D.) [11]. They "contain some of the most impressive monuments in the Islamic World" and compose an intriguing and impressive skyline for the commuters and visitors driving along the new Salah Salim highway into the city [12]. As such the Cities of the Dead, with its largely grid-iron formally planned layout, are beginning to be inserted into more unconventional tourist itineraries diverging from the traditional destinations of the Citadel and the Old Islamic city with its narrow streets and compact urban fabric.

There has long been a numbers controversy over the squatter population of these cemeteries. John Antoniou observes that "various population estimates range between two and five hundred thousand."[12] Similarly it is claimed by Rodenbeck that no-one knows exactly how many people live in the Cities of the Dead [13]. "Estimates range from 50,000 to ten times that number", he writes, because it is hard to define where the tombs end and the living city begins. In fact, because of new roads constructed alongside the perimeters and the relatively uninhabited slopes of the Muqattam Hills and wastelands of Fustat the cemeteries are reasonably well delineated. El Kadi demonstrates how the City of the Dead's population has been repeatedly overestimated, sometimes to as high a figure as between 1 and 2 million people, by the press or by opposition politicians [1] . The Spanish writer Juan Goytisolo also overestimates the population at "almost a million souls", not counting those of the departed [14].

Despite some detailed field visits Nedoroscik suggests that "there could be as many as one million people living in the City of the Dead."[15] El Kadi quotes research by the "Departement de sociologie (avril 1984)", presumably from the University of Cairo, as the basis of another overestimate of 900,000 [2], which contrasts markedly with Abu-Lughod's estimate of "perhaps 100,000 residents" and Gad's (1992) research conclusion of just 275,000 inhabitants [10]. El Kadi herself demonstrates detailed figures for the various cheyakhats, which include sections of the three cemeteries within their boundaries, and these total a much lower figure of 179,057 inhabitants for the late 1980s [1]. Indeed, these census-based figures show a steady but slow growth in the Cities of the Dead population from 30,969 in 1897 to 49,397 in 1927, 81,069 in 1947 and 154, 637 in 1976. Detailed figures presented by El Kadi show that several cheyakhats in fact showed a population decline, 1976-1986, including ElKardi, El-Khawas, and El-Kadreyah, but a doubling of El-Bassatine's cemetery population from 24, 055 to 54,383, rather distorted the picture [2]. Excluding El-Bassatine, the cemeteries' population therefore declined, 1976-1986, perhaps reflecting the more widespread decline of Inner Cairo's population. The tendency to over-estimate the cemeteries' squatter population also applies to the annual growth rates of that population. Generally, as El Kadi's data demonstrates, the cemeteries' resident population has grown at a slower rate than that of the City of Cairo [2]. Gad's figures confirm 
the decline in population growth with an estimated 117000 people living in cemeteries (including tombs and residential in-filling areas) [7] (Table 1)

Table 1. Estimated size of population in cemeteries in Cairo

\begin{tabular}{|l|c|}
\hline Cemetery district: & Estimated population: \\
\hline Ezbet El-Barquoky & 10,000 \\
\hline El-Sharkia El-Muslemein & 4,000 \\
\hline El-Tounsi & 35,000 \\
\hline El-Sadat & 3,500 \\
\hline Omar Ibn El-Fard & 1,000 \\
\hline El-Mogawerein & 15,000 \\
\hline El-Imam El-Shafei' & 12,000 \\
\hline El-Sayeda Aisha & 5,000 \\
\hline Bab El-Nasr & 500 \\
\hline Qaytbay & 10,000 \\
\hline El-Imam El-Leithy & 5,000 \\
\hline Arab El-Yassar & 14,000 \\
\hline Bab El-Wazier & 2,000 \\
\hline TOTAL: & 117,000 \\
\hline \multicolumn{2}{|c|}{} \\
\hline
\end{tabular}

Source: After Gad [7] 
Figure 3. Eastern Cemetery: layout, land use and main monuments

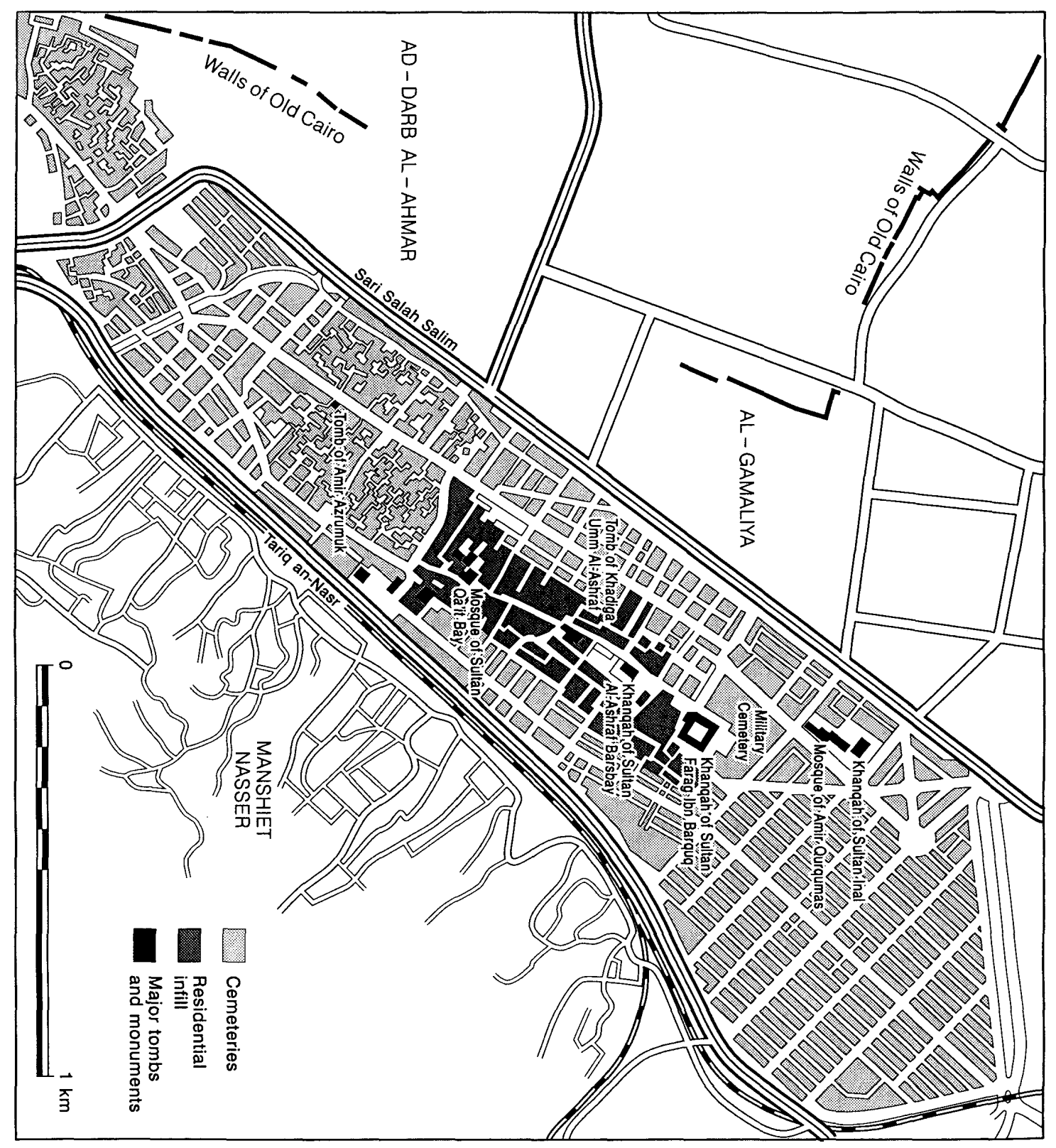

Source: El Kadi [2]; SPARE (Society for the Preservation of the Architectural Resources of Egypt), Guide Map medieval Cairo, No. 4. 1996 
Another exaggeration or myth debunked by El Kadi concerns the fact that most of this 1986 population of 179,057 does not actually dwell in the tombs themselves, despite the popular image usually presented. Certainly some families do dwell in the tomb houses or hawch, making use of their many rooms, their often spacious courtyards, and even their underground vaults. However, El Kadi estimates that only about 15,000 people are proper tomb-dwellers [2]. This compared with CAPMAS's (the State Statistical Bureau's 1986 census) estimates of 13,419 people (Table 2) [16]. A study by the NPC [4] revealed an estimated 3,520 households with an average size of 4.78 person/household, and a total population of 16,825 living in tombs (hawch). This study was based on $80 \%$ of households, with $20 \%$ of them being reluctant to respond through fear of eviction. This survey only took into account permanent residents of tombs, hi contrast the majority of the Cities of the Dead population live in informally built conventional housing constructed in the many hitherto unused spaces (plots) between and around the tombs and mausoleums. This stands out on Figure 2 where central areas of the Eastern Cemetery are occupied by quite densely-built houses, often of several storeys in height, which resemble similar spontaneous urbanisation elsewhere in Greater Cairo. Indeed, any visitor to the Cities of the Dead can readily observe the relatively deserted nature of most of the streets with most of the courtyard tombs remaining locked up and evidently unoccupied by squatters.

Table 2 CAPMAS (1986) estimates of population living in tombs by qism

\begin{tabular}{|l|c|c|}
\hline Qism: & No. of households: & No. of people: \\
\hline Misr al Oadema & 26 & 125 \\
\hline El-Sayeda Zeinab & 166 & 755 \\
\hline El-Khalifa & 1,663 & 6,430 \\
\hline El-Darb El-Ahmar & 47 & 199 \\
\hline El-Gamaliya & 356 & 1,683 \\
\hline Manshiet Nasser & 953 & 4,217 \\
\hline El-Bassatine & 5 & 10 \\
\hline TOTAL & 3,210 & 13,419 \\
\hline
\end{tabular}

\section{Source: CAPMAS [16]}

As well as the exaggerated numbers myth, another inaccuracy clarified by El Kadi [1,2] concerns the fact that the tomb residents, for the most part, were not squatters but rather rented the mausoleums from the undertaker's assistants, often with the knowledge and permission of the families owning the tombs. Rents are fixed according to the situation, area and level of equipment of the tombs. Furthermore, the tomb dwellers agree to move out whenever the owner-family wishes to visit their ancestral tombs. Tomb rents have increased parallel to rents elsewhere in Cairo and consequently the tombs are no longer accessible or affordable for the poorest strata of society.

Tomb dwelling in Egypt goes back to the ancient cemeteries of Thebes. The growing size of Cairo's cemeteries and the increasingly important and architecturally magnificent mausoleums built by the Mamelouks (1250-1570 A.D.), such as the Qait Bey complex (Figure 3), necessitated a growing army of permanent guardians, undertaker's assistants, and other cemetery workers who increasingly resided alongside or even within their places of work, the tombs. During Mohamed All's rule (1805-1841) the building of mausoleums by more noted families became increasingly fashionable, prompting a growth in the related permanent residents of the cemeteries. By the end of the nineteenth century Cairo's urban housing crisis began and added the pressure of early squatters seeking shelter, for whom the vast cemeteries provided a solution of sorts. Thus, by the 1897 census, the cemeteries already 
accommodated 30,969 people, of whom 8,817 were tomb dwellers [2]. A further factor was the improved accessibility of the Southern cemetery when, in 1907, a tramway line was extended into the El-Imam El-Shafei' cemetery, so linking these potential residences to workplaces in central Cairo. Then, after the First World War, rural exodus in-migrants to the capital in part invaded the cemeteries, especially that of the Mamelouks. During the 1930s and 1940s Cairo's population expanded rapidly, housing conditions worsened, and movement to the cemeteries increased. By 1947 the census population of the cemeteries attained 69,367 inhabitants, a doubling over half a century.

From the 1960s onwards, population displacement from Old Cairo, as some buildings collapsed and as others, such as significant mosques and oukalas, were restored and emptied of their squatter populations, put further pressure on the adjacent cemeteries. While some of the original cemetery occupants moved out to spontaneous urban districts like Manshiet Nasser to the east and to ElBassatine to the south, newcomers arrived from inner Cairo. The period 1960 to 1976 therefore saw an annual $2.4 \%$ growth in the cemeteries' population [2]. While rents for the tombs remained reasonable (between 5 and 20 LE a month), the gate-keeper croque-morts (torabi) exacted 'key money' sums of between 10 and 1200 LE so debarring the poorest elements. According to NPC's study $12 \%$ of households paid rent, nearly 59\% dealing with the gate-keeper [4]. Rents ranged from 10 LE (11\% of those paying rent), $10-20 \mathrm{LE}$ (58\%), and the rest paying more than 20LE a month. More than half the residents who did not pay rent were helping the tomb guard (ghafeer), or gate -keeper (torabi) with his work, whilst the rest were either living with relatives or were hawch owners. Instead of living in the tombs most of the poor resorted to more conventional squatter huts as between the wooden tombs in the Bab El-Nasr cemetery or on the roofs of mausoleums in the El-Sayeda Nafeissa cemetery. On a larger scale shantytowns developed on the edges of the cemeteries and on vacant land within them. According to Gad reasons given by respondents for dwelling in tombs involved the collapse or deteriorating conditions of their original residential building within Old Cairo districts close to the Eastern Cemetery, such as El-Khalifa, El-Darb El-Ahmar, and El-Gamaliya [7]. Nevertheless nearly $80 \%$ of the NPC's sample came from other districts in Cairo and not from the Old City. While $13 \%$ of El Kadi's sample surveyed were born in the cemeteries, the other $87 \%$ had moved in from other parts of Cairo [2]. However, 45\% were originally rural in-migrants born outside of Cairo. In addition rural migration to Cairo was mentioned as a cause for moving into tombs which had relatives already living there (28\% according to NPC [4]). For people with a rural background the cemeteries represented a refugee setting and way of life similar their original villages, with nearly $64 \%$ having no other alternative place to live. Other variables included housing shortages and high rents, large family size , low income levels, official eviction orders, and type of work related to cemeteries (such as maintaining tombs, guarding cemetery, burial ceremonies) (Table 3). 
Table 3 Some Reasons behind living in hawch

\begin{tabular}{|l|c|c|}
\hline Reasons: & No. of households: & $\%$ \\
\hline No other place & 958 & 64.0 \\
\hline $\begin{array}{l}\text { Lack of room in previous } \\
\text { residence }\end{array}$ & 27 & 1.8 \\
\hline Rent too high & 169 & 11.3 \\
\hline House collapsed & 116 & 6.7 \\
\hline Proximity to work & 92 & 12.1 \\
\hline $\begin{array}{l}\text { Type of work linked to } \\
\text { cemetery }\end{array}$ & 182 & 28.1 \\
\hline Living with relatives & 422 & \\
\hline
\end{tabular}

\section{Source: NPC [4]}

The following respondents' statements illustrate some of these reasons:

" I have 7 children and my monthly salary in the Ministry of Waqf is 105LE so I moved to the cemetery and I live in the tomb for free and could find work as well" - a 58 years old civil servant

" I am from Assuit - when the tomb owner sympathised with my case as I was homeless and broke and offered me the chance to look after the hawch and live here also" - a 65 years old man

" When we were living in Manshiet Nasser before, there was no privacy. It was unsafe and violence prevailed so we preferred to live with the dead" - a 35 years old truck driver

(NPC [4])

\section{Socio-Economic Characteristics of the Tomb Dwellers}

An early factor analysis of the 1960 population of the Cities of the Dead by Abu-Lughod suggested a low status population showing an affinity with rural fringe populations [10]. Some subsequent detailed research by El Kadi [2] and by CAPMAS [16], especially focused on the inhabitants of the tombs (hawch). permit some socio-economic aspects to be discussed. These often reveal a more positive situation with respect to the cemeteries' squatter community, which often fits in with reassessments of squatter settlements by Turner [17] and Mangin [18] as being inhabited by fairly dynamic groups of people. However, this could not be demonstrated by the level of satisfaction as expressed by respondents living in hawch. Female respondents were discontent with the standards of living with nearly half being fearful and insecure concerning the high percentage of violence and abuse against women. Others were fearful of evil spirits within the cemeteries.

" Now the cemeteries are very dangerous " - a 40 years old woman

"We are not allowed to leave the house after sunset because of the threat of attacks and abuses" - a 17 years old girl

"I lived in the cemeteries for the last five years and have not seen or experienced any ghosts. This is just a myth based on people's imagination and inventions" - a mosque caretaker in his $50 \mathrm{~s}$. 
About 8 out of 10 households in the NPC study found the hawch unsuitable for maintaining a sustainable lifestyle, this attitude being significant amongst $70 \%$ of households with children [4]. When asked whether they would move out of the tombs if given an alternative , $87 \%$ gave a positive response with nearly two thirds willing to pay between 30-60 LE a month which would be nearly two or three times their current rent.

The NPC survey has revealed a balanced gender ratio except for the age group between 20-49 where there were more females than males (Table 4) [4]. Nearly one third of the population in hawch were less than 15 years of age. Such figures indicated a high dependency rate within hawch society (63\%) with a considerable percentage of the youth involved in marginal work within the informal economy as well as within the cemetery sector

Table 4 Age and gender structure of households - 1500 households

\begin{tabular}{|l|c|c|c|}
\hline Age group: & \% male: & \% female: & \% total: \\
\hline $0-9$ & 21.4 & 20.0 & 20.8 \\
\hline $10-19$ & 26.6 & 28.2 & 27.0 \\
\hline $20-29$ & 17.4 & 18.8 & 18.1 \\
\hline $30-39$ & 12.6 & 14.2 & 13.5 \\
\hline $40-49$ & 10.3 & 13.5 & 11.9 \\
\hline $50-59$ & 7.1 & 2.3 & 4.7 \\
\hline 60 and above & 4.6 & 3.7 & 4.1 \\
\hline
\end{tabular}

\section{Source: NPC [4]}

As many as $73 \%$ of the population over 15 years of age had a job according to El Kadi [2]. This contrasts with the NPC figure of $48 \%$ of those living in hawch [4]. The unemployed component is made up largely of housewives, the retired and the infirm. Those working were divided into artisans/ craft workers (31\% according to El Kadi [2] rising to 50\% of the NPC sample [4]), civil servants (20.1 $\%$ in 1995 falling to $14.6 \%$ in the 1999 study), day labourers (12.8\% in 1995 and $7.4 \%$ in 1999) and undertakers' assistants and gravediggers (8.1\% in El Kadi [2] increasing to $14.1 \%$ in NPC [4]). The rest included tomb guardians and ill-defined occupations. Only $10 \%$ of the sample surveyed worked in the cemeteries, the rest travelled to employment outside. However most of those are employed in seasonal work, apart from civil servants. This contributed to a feeling of financial and social instability, as well as marginalisation within their own community and in relation to the rest of Cairo's people.

Hence illiteracy levels were high at $64 \%$ [2] showing some improvement in 1999 when figures dropped to $40 \%$ of sampled households in the NPC study [4] (Table 5). There were no major differences between males and females in terms of education, with nearly $40 \%$ of those who have been to school never obtaining any qualification. There was an insignificant but intriguing percentage of $2 \%$ of the NPC sample who went on to higher university-level education. Given the lack of educational facilities within cemeteries most children go to schools outside the area (nearly 53\% of hawch in the Eastern Cemetery are located close to schools) [4]. 
Table 5 Educational status within households - 1500 households

\begin{tabular}{|l|c|c|c|}
\hline Qualification: & Male (\%) & Female (\%) & Total (\%) \\
\hline None & $\mathbf{4 3 . 4}$ & $\mathbf{4 1 . 9}$ & $\mathbf{4 2 . 7}$ \\
\hline Primary & 23.0 & 23.9 & 23.5 \\
\hline $\begin{array}{l}\text { Intermediate (12-14 } \\
\text { vears old) }\end{array}$ & 15.7 & 15.7 & 15.7 \\
\hline Secondary & 15.5 & 17.0 & 16.2 \\
\hline University & 2.4 & 1.6 & 2.0 \\
\hline Total: & 100 & 100 & 100 \\
\hline
\end{tabular}

\section{Source: NPC [4]}

Nevertheless reasons given by respondents for their children not going or dropping out of school ranged from financial inability, assisting their families in cemetery work, psychological exclusion from mainstream society and lack of security within the area. Some examples can be quoted:

"I have nine children and my daily income is around 7-8LE. So how can support their education?" - a 65 years old man

"I am raising up a child so he can help me when he grows up . I consider him a source of income and future investment. Education is just a waste of time and money." - a mechanic

"My son dropped out of school because he was embarrassed to tell his colleagues at school that his father is a tomb keeper" - a 37 years old woman

"My daughter finishes her classes in the evening and I have to escort her every time back to the hawch" - a 42 years old woman

"I need to attend some additional courses but my father has prevented me from leaving the hawch after 4:00pm" - an 18 years old girl

"I will make sure that all my children will go to school. My elderly sister has finished University and all ten of us are in various levels of education" - a university student

(NPC [4])

As many as $21.4 \%$ of El Kadi's sample had been living in the cemeteries a long time having arrived there before 1945; another $46 \%$ had moved in between 1955 and 1974; leaving $32.6 \%$ as recent immigrants arriving between 1975 and 1985 [2]. This data suggests that up to third generation tomb dwellers were now living in the Cities of the Dead. However crowding rates within the hawch (2.7 persons/room) revealed that $88 \%$ of the NPC sample lived in 2 rooms or less and this was regarded an indicator of poor environmental conditions and low economic, social and health standards [4]. Facilities within the cemetery contributed to the low standards of living with services being brought in legally or illegally to only a limited extent. Of the tomb dwellers only (excluding the rest of the cemeteries' squatter inhabitants), $53 \%$ were linked to piped water networks and $26.2 \%$ to electricity services, but only $3.8 \%$ to a sanitation system. The NPC surveyed 17 cemeteries where they noted sources of potable water inside and outside the hawch_except for El-Nakhal and El-Gafeir cemeteries [4]. Twelve of the cemeteries had electricity, nearly all of them with street lighting. The exceptions were El-Tahawiya, Zein El-Abidin, El-Bassatine, and Sidi Galal. Only two cemeteries (El-Azra'iya and 
El-Nakhal ) had no electricity either inside or outside the hawch. Health facilities were limited to only three of the cemeteries surveyed and less than half of them had paved streets. Nevertheless these figures reflect a dramatic improvement in service facilities for hawch residents (Table 6) [4].

Table 6 Type of service facilities within hawch (1500 cases)

\begin{tabular}{|l|c|}
\hline \hline Location of Kitchen: & \\
\hline \hline Inside hawch & $44.3 \%$ \\
\hline Outside & $1.2 \%$ \\
\hline \hline Type of Kitchen: & \\
\hline \hline Individual & $93.7 \%$ \\
\hline Common & $6.3 \%$ \\
\hline \hline Source of Power: & \\
\hline \hline Butagas & $76.3 \%$ \\
\hline Kerosene & $23.1 \%$ \\
\hline Electricity & $0.4 \%$ \\
\hline Other & $0.3 \%$ \\
\hline \hline Source of Drinking Water: & \\
\hline \hline Public tap & $37.7 \%$ \\
\hline Inside hawch & $30.4 \%$ \\
\hline Water Cart & $30.1 \%$ \\
\hline Other & $1.7 \%$ \\
\hline \hline Source of Light: & \\
\hline \hline Electricity & $7.8 \%$ \\
\hline Kerosene & \\
\hline Other & \\
\hline \hline Type of Toilet: & \\
\hline \hline Flush Toilet & \\
\hline Earth Closet & \\
\hline Trench & \\
\hline Outside & \\
\hline Other & \\
\hline
\end{tabular}

Source: NPC [4] 
Some comments from hawch dwellers are illuminating:

"We take electricity from the main public source and sometimes we share the same connection with our neighbours . This is illegal but we do not have any other option." - a 37 years old woman.

"Once a girl had to travel at night for a long distance to get access to a water source. She was assaulted and raped and nobody dared to press charges." - a tomb keeper in his 60s.

(NPC [4])

To turn to consumer durables. El Kadi found that $25.5 \%$ of households had a fridge, $12 \%$ a colour TV plus $35 \%$ with black and white TV, and $20.4 \%$ had washing machines - all presumably operating within tombs [2]. According to NPC's later figures, 8 out of 10 households within hawch possessed a radio or radio-cassette player, 4 out of 10 had a colour TV and fridge, one third had a black and white $\mathrm{TV}$, and 4 out of 10 owned a video, a sewing machine and an electric fan (Table 7 ) [4]. The higher levels of ownership suggest recent improvements in living standards.

Table 7 Consumer durables within households living in hawch

\begin{tabular}{|c|c|}
\hline Consumer durables: & $\%$ possessing consumer durable: \\
\hline Radio-cassette & $86.6 \%$ \\
\hline Colour TV & $45.2 \%$ \\
\hline Black and white TV & $35.3 \%$ \\
\hline Video & $4.3 \%$ \\
\hline Fridge & $43.5 \%$ \\
\hline Kerosene or electric oven & $59.6 \%$ \\
\hline Water boiler/heater & $3.7 \%$ \\
\hline Sewing machine & $3.7 \%$ \\
\hline Electric fan & $31.1 \%$ \\
\hline Electric washing machine & $71.3 \%$ \\
\hline
\end{tabular}

Source: NPC [4]

\section{Social Structures and Social Stigmas and Built Environment Conditions}

A four-fold hierarchical social structure could be detected amongst the tomb dwellers. At the top of the hierarchy were the undertaker's assistants and Waqf civil servants, both groups concerned with managing the activities of the cemeteries. Secondly came a group including craft-workers, small businessmen, owners of small workshops and major gravediggers. The third category was composed of civil servants, office workers, day labourers, and lesser gravediggers. At the base of the social hierarchy were the retired, elderly, infirm, hawkers and the unemployed. Apparently certain more middle class occupations were found because some families had been compelled to seek refuge inside their ancestral family tombs following the collapse or the destruction by an earthquake of their original house or apartment block [2].

Despite this evidence that the socio-economic profile of the tomb dwellers approximates to that of the poorer quarters of Greater Cairo, there still remains much social stigma attached to a cemetery address. The popular perception of the inhabitants of the Cities of the Dead is still negative and pejorative. They are still seen as a threat to social order, as fugitives from justice, and, recently, as drug traffickers. Long-established negative images remain despite the general academic rehabilitation of 
squatter settlements and their inhabitants $[17,19]$. The self-image of the tomb dwellers and other residents of the Cities of the Dead is undoubtedly different. Tomb dwellers will appreciate the relative accessibility of their cemetery districts compared with distant New Town or New Settlements locations. They will also value the relative low population density of the cemeteries, especially in the tombs compared with the shanty infill areas, and the quiet streets compared with the congested and often grid-locked streets of Cairo's CBD and other inner city districts. This was recognised by AbuLughod who suggested that "it is inevitable that some of her (Cairo's) citizens will prefer the air and openness of the cities of the dead to the oppressive crush in the cities of the living." [10]

Major urban and physical problems within cemeteries especially the Eastern Cemetery were surveyed by GOPP in terms of their inefficient location between two main road traffic arteries (Salah Salem Street and the Autostrada)[3]. This does not permit future horizontal expansion. This situation was compounded by the presence of historical monuments and mausoleums as part of Cairo's heritage, all under threat from bad maintenance and environmental degradation. The in-migration of rural population has contributed to over-crowding and with the lack of public services and infrastructure there is a need for a major service and upgrading programme. The GOPP study of 918 hawchs in the Eastern Cemetery revealed many distinctive monumental elements and stressed identifiable boundaries around the cemetery district [3]. Mixed-use activities were observed within the urban area in terms of spontaneous residential structures, commercial and workshop activities (Figure 4) The selected area was subdivided into centre and periphery (adjacent to Salah Salem Street and to the Autostrada). The physical survey focused on building conditions, heights, uses, types of cemeteries, building materials, ownership patterns, and architectural style (Table 8).

Table 8 Physical survey of the street frontage of 918 hawchs in the Eastern Cemetery

\begin{tabular}{|c|c|c|c|}
\hline & Central area & Peripheral areas & Total area \\
\hline Present conditions: & \multirow{5}{*}{$\begin{array}{c}\% \\
23.5 \\
47.2 \\
27.3 \\
\\
2.0\end{array}$} & \multirow{4}{*}{$\begin{array}{c}\% \\
17.2 \\
37.7 \\
42.6\end{array}$} & \multirow{4}{*}{$\begin{array}{c}\% \\
20.2 \\
42.3 \\
35.2\end{array}$} \\
\hline Degraded & & & \\
\hline Average & & & \\
\hline Good & & & \\
\hline Vacant & & 2.5 & 2.2 \\
\hline No. of storeys: & \multirow[b]{2}{*}{68.1} & \multirow[b]{2}{*}{95.8} & \multirow[b]{2}{*}{82.5} \\
\hline $1-2$ & & & \\
\hline $3-5$ & 29.4 & 1.7 & 15.1 \\
\hline $5+$ & 0.5 & 0 & 0.2 \\
\hline Vacant & 2.0 & 2.5 & 2.2 \\
\hline Uses: & \multirow{3}{*}{31.4} & \multirow{2}{*}{43.0} & \multirow[b]{2}{*}{37.4} \\
\hline Residential & & & \\
\hline Mixed (Residential and & & 37.4 & \multirow{2}{*}{$\begin{array}{c}36.8 \\
5.1\end{array}$} \\
\hline Commercial) Services & 6.5 & 3.6 & \\
\hline Monumental & \multirow{2}{*}{$\begin{array}{c}23.6 \\
2.0 \\
\end{array}$} & \multirow{2}{*}{$\begin{array}{c}13.5 \\
2.5\end{array}$} & \multirow{2}{*}{$\begin{array}{c}18.5 \\
2.2\end{array}$} \\
\hline Vacant & & & \\
\hline Building Materials: & \multirow[b]{2}{*}{9.9} & \multirow[b]{2}{*}{3.2} & \multirow[b]{2}{*}{6.4} \\
\hline Concrete & & & \\
\hline Bricks & \multirow{2}{*}{32.5} & 17.0 & 24.5 \\
\hline Stone & & \multirow{2}{*}{$\begin{array}{c}75.4 \\
1.9\end{array}$} & \multirow{2}{*}{$\begin{array}{c}64.5 \\
2.3\end{array}$} \\
\hline Timber & $\begin{array}{c}53.0 \\
2.6\end{array}$ & & \\
\hline
\end{tabular}

Source: GOPP [3] 
Figure 4. Part of the Eastern Cemetery: aspects of street frontages
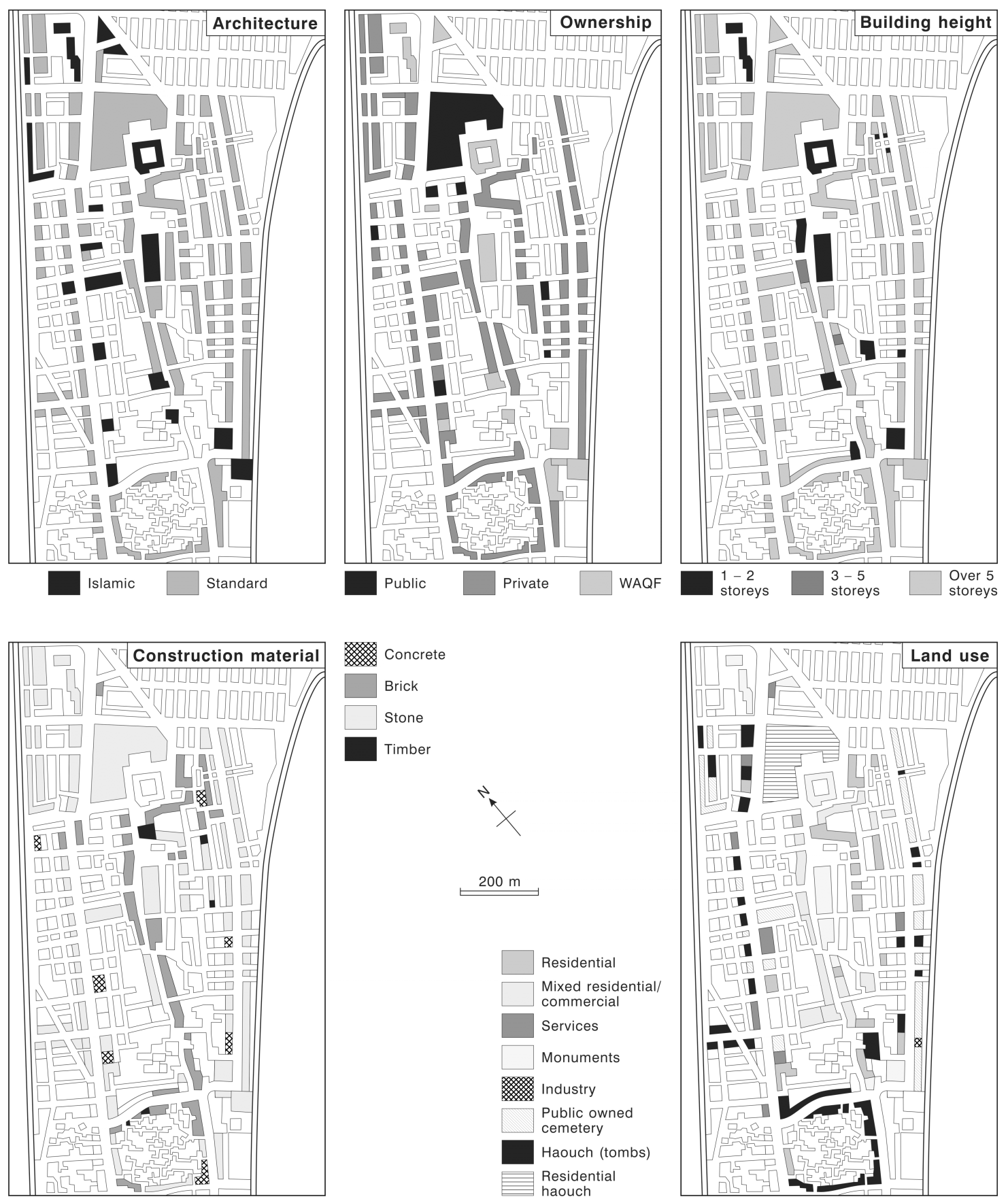

Source: GOPP [3]

Note: Because of difficulties of access off the main streets the GOPP survey restricted itself to the street frontages of the tombs. 
Nevertheless the survey has shown that most buildings in the area are in good to average condition (80\%), with more deteriorated cases being located towards the central area. There was a variegated urban fabric with lots of encroachment and 3\% of the area vacant which could then be in developed into open spaces. More tall buildings were observed near the peripheries though $30 \%$ of buildings in the central part were 3-5 storeys high (especially monuments) and were considered as urban boundaries within the cemetery. Pure residential activities and mixed activities within the hawch were prevalent amongst less than three quarters of sampled cases with few tombs still being used for burials. Services within the area were limited apart from a few primary schools within the central part of the cemetery. Wall bearing construction was regarded as the main pattern using stones with some use of reinforced concrete structures recently as a result of hawch expansion. When considering that $90 \%$ of sample cases were privately owned, one could anticipate some problems if the government were to proceed with eviction plans and the evacuation of tombs.

However the GOPP proposal has suggested a few development potentials for the area including the visual and historical improvement of particularly significant historical buildings through the creation of open spaces surrounding monuments in order to facilitate access and services [3]. There is a need for the provision of pedestrian paths from main access and transport arteries together with the introduction of major tourist activities which would be connected with the CBD and the Old City. Improvement of housing conditions is a prerequisite within the cemeteries at least for the near future until alternatives are provided for, with development control mechanisms being imposed to prevent future encroachment and urban expansion. There is an immediate intervention plan to upgrade surrounding districts, particularly Manshiet Nasser settlement, enhancing its visual connection with the Old City and historical core through the newly created open areas within the Eastern Cemetery.

\section{Scenarios and Plans}

The GOPP has also recommended the transfer of both the cemeteries and their squatter populations, with the relocation of people to the new settlements and the redevelopment of the existing cemeteries area for urban upgrading and environmental improvement. These recommendations identified the need to re-plan and redevelop and reuse the cemetery areas according to the detailed GCR (Greater Cairo Region) Plan with cemeteries representing potential locations for future urban development. The provision of alternative sites for cemeteries is a priority outside the Ring Road. There is a need to take into consideration relocating people living in cemeteries, including those living in residential infillings, to new settlements and treating them as priority groups. The significance of implementing eviction orders is emphasised with such transfer, relocation and improvement schemes. These would be part of a comprehensive programme with appropriate time scheduling and planning procedures. Such a phasing strategy should declare the area as an emergency area in urgent need for maintenance , improvement and preservation of monuments whilst preventing future burial activities.

Government policy towards the Cities of the Dead has been limited so far. Inaction rather than active policy initiatives has prevailed. Certain services such as primary schools and police stations have been extended to the cemetery residents. In 1990 IAURIF/GOPP drew up a redevelopment plan for the Bab El-Nasr cemetery and some of its squatter population of 1500 in 1987 were moved out in anticipation of further action in this area just north of Old Cairo. Part of this North El-Gamaliya Project concerns the area north of the Fatimid walls and the Bab El-Futuh, which is largely composed of a cemetery plus some polluting industrial units. Along with the relocation of the industries the cemetery area will 
be converted into a green space or garden district within which tourist accommodation composed of two hotels plus a commercial centre and car parks would be constructed [20,21].

People interested in the Islamic architectural heritage revealed their concern about preserving the historical monuments, particularly within Bab El-Nasr Cemetery, for both Cairo's residents and for tourists.. Generally, for them the demolition of the cemeteries will destroy part of Cairo's historic past. They want more open discussion about the government's proposals. Consequently, the future of the Cities of the Dead remains ambiguous unless the authorities look strategically beyond the current land use and housing problems to the reasons behind the existence of this unique squatter community.

Long term scenarios have been suggested which would involve the relocation of the squatter inhabitants and the refurbishment of the cemeteries. Alternatively the relocating of the cemeteries further out into the desert has been put forward. The area hitherto occupied by the Cities of the Dead could then be redeveloped for residential purposes, presumably keeping intact the main mausoleums and mosques of historical significance. A contrasting scenario would be to accept the potential contribution of the approximately 250,000 tombs as a stock of housing, albeit unconventional. The de facto role of the Cities of the Dead could be recognised and basic services upgraded and brought into the cemetery areas. Deficiencies in terms of schools, shops, clinics, etc. could be reversed. The whole district could be better integrated with adjacent conventional spontaneous urbanisation as in Manshiet Nasser and El-Bassatine. A third scenario would be to redevelop the cemeteries to focus on their historical, architectural and heritage significance. With landscaping and improved accessibility recreational and touristic use could be made of the area, extending the nearby Citadel's tourist activity into the cemeteries. The proposed redevelopment approach to the North El-Gamaliya cemetery district of Bab El-Nasr could be extended to the whole of the Cities of the Dead. However, given the prevailing myth of a larger population of squatters than is actually there, the likelihood is that nothing will be done and the present situation will prevail despite the its inadequacies and on-going problems.

\subsection{The Case of Clearing Bab El-Nasr Cemetery}

As early as the late 1960s Abu-Lughod had recognised the official desire to reclaim the land occupied by the Cities of the Dead [10]. She stated: "the future of this city [City of the Dead] is moot. Cairo's planners eye the district covetously but in secret, for here is a logical direction into which the cramped city might expand, if only the tombs could be removed." However, she added: "But the sheer size of the zone and the permanency of many of the tomb structures, as well as their high artistic merits, defy simple clearance, even if the revulsion against disturbing the dead could be overcome." [10]

"The City of the Dead has to be removed from the living heart of our capital" stated Cairo's former Governor (1991-1997) [15], so demonstrating the government's thinking about the future of the cemeteries. Consequently early official plans were to move the cemeteries to a new desert location by the Cairo to Suez road and then to reclaim the land occupied by them now for new business and tourism projects. The families currently living in the tombs would be compensated and provided with alternative housing.

According to Nedoroscik plans for the clearing of the Bab El-Nasr Cemetery were already underway as part of the North El-Gamaliya Project [15]. The significance of this cemetery is mainly attributed to the fact that it houses the graves of Badr EI-Gamaly (the founder of the Gamaliya quarter), El-Maqrizy (the great historian), Ibn Khaldoun (the pioneer social reformer) . Additionally, the cemetery is famous for its unique architecture of wooden tombs, varying between one and two floors, with balconies and 
loggias ornamented by lace-like wood works and timber domes, adopting Ottoman styles with Roman and Coptic architectural details. In 1984, a decision was announced to demolish this cemetery and replace it with a large public garden. This decision was followed up by a partial demolition in 1989 that has resulted in the destruction of some important graves. Strikes by professionals and historians led to the formation of a committee that arranged a documentary exhibition on the origins and development of this cemetery, proposing the transformation of the cemetery into a public garden, whilst preserving the significant tombs within the natural topography, and emphasising the varied architectural forms. Disappointingly, the Supreme Council of Antiquities did not support this project and the area has recently been bulldozed and paved over with streets and parking areas . Consequently, the people residing in this cemetery were to be relocated to new communities outside of Cairo's urban fringe and the tombs replaced by upper and middle class houses, public parks, and a new luxury hotel development. By early 2000 the Bab El-Nasr cemetery was still extant if rather empty of obvious tomb dwellers.

Following an official removal of part of the Bab El-Nasr Cemetery by mid 2001 (clearing 35 metres within the cemeteries in order to widen Salah Salem Street), the current study administered a small area survey (of 40 households- $40 \%$ of relocated households) within the Cemetery employing direct observation, and open-ended interviews with affected relocatees (40 heads of households), as well as interviews with officials concerned with demolition procedure and resettlement programme. Interestingly enough the study survey revealed that there was a considerable number of people residing in tombs, with an approximate 500 people (nearly 100 households) being forcibly moved out of the cemetery's wooden tombs as result of Cemetery clearing procedures. Resistance to the eviction scheme was noted amongst $75 \%$ of the relocated household ( $\mathrm{n}=30$ households), with women and elderly members of the community 50 years and above expressing more anxiety, as compared to age groups between 20-39, in relation to their inability and un-affordability to find an immediate alternative residence.

Whilst $15 \%(\mathrm{n}=6)$ of the evicted households squatted into unused historical monuments close to the Northern Gates of the Old City, 25\% $(n=10)$ occupied the evacuated informal housing units which were hardly affected by the 1992 earthquake. Nearly one third $(n=12)$ the relocatees, with rural background and affiliation with relatives living in surrounding settlements, moved east to the spontaneous urban district of Manshiet Nasser. Households who were involved in work as tomb guards (ghafeer) or gate keepers (torabi) $(30 \%(n=12)$ of sampled households) resorted to more conventional squatter huts, and tents in vacant land pockets between tombs in the eastern cemetery. As a result a shanty town started developing on the vacant land on eastern fringes (3\% of the area) close to Salah Salem street and the autostrada. Such encroachment would affect the proposed immediate intervention plan to develop newly created open areas within the Eastern Cemetery, (whilst upgrading Manshiet Nasser settlement, and enhancing its visual connection with the Old City and historical core.)

Most respondents $(80 \%)(n=32)$ mentioned that one direct effect of tomb dwellers' eviction and removal of Bab El-Nasr Cemetery was the disruption of economic structure (especially amongst guardians of tombs), social ties and community networks which nevertheless characterised Cairo's urban poor within other low income and deprived areas. Amongst the residents reactions range from skepticism about the government's ability to deliver appropriate alternative housing $(30 \%-n=12)$ to those extremely poor tomb dwellers who welcome official proposals $(25 \% \mathrm{n}=10)$. Others are content with their lives in the cemeteries and defend their position as tomb dwellers, regarding the area now as their home $(45 \% \mathrm{n}=18)$. However, the issue of compensation is raised in terms of who would be eligible. Questions were posed of whether there would be enough replacement housing, where it would 
be located and would it be accessible to employment and to services such as education and health centres? [15]

Security of tenure in new settlements was one of the respondents' major concerns, in terms of their hesitancy to invest in developing an area from where they can be evicted at any time. Accordingly cemeteries can in fact be regularized, despite the local authority's claim of lack of resources, both financial and human, as the major constraint to this process, whilst involving a complex procedure full of bureaucratic delays and of quite considerable expense ${ }^{1}$. However NGOs can help people obtain a stay order from the courts to halt the demolition of their original settlements within the Cemeteries, whilst providing legal and other advice to those who are evicted. But this was not followed by a sustained campaign in support of their case, and in the absence of a strong local people's organization, cemetery inhabitants were evicted.

The situation was more stressful for those who have set up informal enterprises in the cemeteries, such as shops and workshops $(35 \% \mathrm{n}=14)$. They fear losing both their shelter and source of livelihood as do the tomb-keepers and undertakers. Hence Nedoroscik suggests that the Government should consider which should take greater priority, reclaiming land with a valuable location or improving conditions for a significant segment of Cairo's urban poor [15]. How should economic gains be weighed against the valid concerns of tomb owners and residents over compensation and new cemetery locations?

The study survey illustrated case histories of various female heads of households who described their lives after eviction from the Bab El-Nasr Cemetery to the Eastern desert settlements, as "Out here, there is nothing..." where some of them moved twice, choosing to live initially in temporary tin huts or tents on vacant land within fringes of Eastern cemetery, and then forced again to settle in Cairo's Eastern desert Communities;

"Look what we have got... nothing. There is no water, no electricity...Nobody is going to help us. I worry about how I am going to feed my six children."

"The local officials for our area told us we had to get out. We asked where we could possibly go, and were told not to worry, as we would be provided with alternative plots. Some of the men did not agree to this. as there was nothing in this new place. And then. what about our livelihood? The local officials told us that in a week's time all facilities would be given to us. We were sceptical but what could we do? We are poor people, we have no money, no power. We had no options."

"The local authorities arrived with the police and a lot of other people and told us to pack our things, saying that they were going to shift us to Cairo's New Eastern desert Communities (fringes of New Cairo City). What would happen to our children? How will we feed them? What about our homes?"

"We couldn't do anything, so we packed up our few belongings, tried to salvage what we could from our homes. .... We had managed to save some money to introduce modifications to the tombs with such great difficulty and they were now going to be destroyed."

"We have been given plots (areas $=60-100$ square meters) in the new desert settlements. ...How can we build our homes there ? ...The plots cost approximately 5000 LE (One 
$\mathrm{USD}=7$ LE August 2014 rates)) which we have to pay in only two installments. We can't afford 2500 LE..How can we save? Who will give us a loan?".

" The local authorities said that within a week (after arriving at the new plot in new eastern settlements of Cairo) we would be given all facilities. We don't have any latrines . All we have got is a water tap. There are about 300 families here. Some of us don't get any water, so we have to share ".

" In Bab El-Nasr Cemetery at least we were in the centre of the city, we could get Jobs. The men could earn some money to feed their families. Out here there is nothing. Some of us had shops, or a tea cabin, while most of the women like me worked in different areas nearby doing housework. We earned about (125-150 LE) Now, this place is so far from the city that we have to spend (5LE) a day on transportation."

" Most men were involved in burial activities within the tombs. earning a daily wage. Some worked as hawkers. Who will buy their stuff? The main road is so far away. We also need money to buy something to sell. Who has the money?"

"Now the women have to work. We spend at least two hours going and coming to work. If I don't work, our families will starve. Everything is so expensive... Only the poorest came out here. Those who had a little money did not shift here. They rented a place in Manshiet Nasser or somewhere else nearby. They said that at least they were close to their source of livelihood. If we had some money, maybe we would also move somewhere close to our work place. Nobody cares for us and nobody will do anything for us. We will just have to slowly rebuild our homes all over again."

\subsection{Tomb Dwellers in the Post 2011 Era}

Another follow-up small area field study was conducted in 2014 with few primary stakeholders' narratives in order to explore the impact of 2011 uprising on the situation in the northern cemeteries. As a result of lack of security since the uprising and the continuous insurgence, there was difficulty in obtaining reliable data for the analysis of the post 2011 situation, apart from few local people's narratives .

However, similar causes that have motivated the post 2011 uprising protests ranging from political repression, lack of democratic freedoms and unsatisfactory neo-liberal economic policy reform to poverty and high unemployment rates, must all be taken into consideration, when assessing the cemeteries' future. Tomb dwellers expressed their discontent with the degraded standards of living and lack of security since 2011, as noted in their various narratives:

"Now the cemeteries are very dangerous. We are not allowed to leave the house after sunset because of the threat of attacks and abuses".

"After 2011 uprising, we have experienced more economic hardship, with our settlement suffering environmental degradation as a result of inefficient infrastructure, lack of state policing within the area, insecurity and lack of safety, political instability, social unrest and insurgence, insufficient state subsidies, and decline in service sector". 
"We thought that the uprising will improve our living conditions. but after three years the situation is getting worst. I hope the government would support us by consolidating the security situation, despite the fact that they [officials] want us out of the area."

"We have demonstrated few times and have blocked the autostrade to let the government realise our demands. We need some security back in the area so we can work safely."

"We have lost a lot of money because of rise in fuel and food prices. I have been struggling to provide enough food for my wife and three children, since I have hardly secured the same pre 2011 daily income. Sometimes we do not work for days especially during riots and insurgence."

Tomb dwellers' integration into the formal societal system depends on the outcome of the current state of upheaval within Cairo and Egypt since the 2011 uprising. Nevertheless, dispossessed societal groups like the tomb dwellers may be more adequately equipped to deal with the post 2011 uprising uncertainties and difficulties that have characterised their existence for decades.

\section{Conclusion: The Future of the Cemeteries}

Community leaders emphasised four main failings (no warning, no consultation, no compensation and no provision for resettlement) however as contributing to the lack of any attempt to develop solutions which minimize the scale of the evictions and the disruption caused to those who have to move. The trauma of evictions where cemetery people are forced from their homes in the tombs, in which they have lived for decades and in which they have often invested a considerable proportion of their income over the years - their possessions, as no warning is given before the bulldozers destroy their settlement, and the often complex reciprocal relationships which provided a safety net of protection against income decline or the loss of a job. They often lose one or more sources of livelihood as they are forced to move away from the area where they had jobs or sources of income. Where provision is made for resettlement, this is almost always at a distant site where the people are expected to build, once again, their homes but on land with little or no provision for Infrastructure and services. Those evicted rarely receive any financial support for rebuilding. The land site on which they are relocated is also very often of poor quality

The Government's programme aimed to stimulate upper and middle-class residential construction by clearing such strategically central areas of the city from the presence of the poor. Needless to say, all of this was done In the name of the government's concern for the welfare of the 'less favoured' families, with legislation to protect "the environment" as a justification for securing access to land for development. Such forced evictions within the cemeteries reflect the differences in political power within the society, where economic interests resort to the law or to municipal authorities who have the power to evict people "In the public good".

In this case local governments played a major role in initiating the evictions (for public works or city beautification programmes), where the supply of land for housing is constrained and the cost of the cheapest house or site artificially raised by Inappropriate or inefficient bureaucratic controls. It is this combination of a high proportion of city populations with very limited incomes, and high housing and land prices which ensure that the cheapest legal accommodation is beyond their reach, thus forcing them to enter the illegal housing and land markets. The Cemetery people, considered part of Cairo's 
urban poor have a far weaker legal position from which to fight eviction or at least to negotiate concessions (for time and support for moving and acquiring alternative accommodation) and compensation. Many low-Income people within the Cemeteries facing the threat of eviction point out how it is their cheap labour that underpins the city's economy, yet the city has no legal accommodation which they can afford.

This fact is evident in the words of a female respondent,

"..we contribute to the city's economy and support through our labour the very people who want us to move.... why then are we pursued so persistently?"

Or the words of a woman questioning the endless evictions which dispossessed the poor

"....we do not claim much. We are not demanding free accommodation. We do no pretend that we are living like other Cairene middle-class. We wish to live in cheap housing. Why is it not allowed?"

It has been repeatedly observed that illegal occupations of tombs are severely repressed by a combination of municipalities, tomb owners and governments, whilst forming an alliance with the judicial system. However, the government has established two kinds of relocation sites: transit camps for displaced persons and resettlement sites for squatters, where conditions in new sites are poor, without employment opportunities, and with few services. Interviews with key government officials revealed their justification for such eviction schemes as being attributed to "improving" or "beautifying" the city. Such authoritarian approach is more likely to implement such plans with largescale evictions; a lack of dialogue with poor cemetery people and their organizations, a lack of representation of their views within government, greatly reduces the possibility of successful opposition to such plans. There is no/lack of negotiation of a compromise between the local authorities undertaking the redevelopment and those groups who are to be evicted Additionally officials claim that such "slums" are centres of social problems, thus, evictions not only make the city more beautiful but rid it of squatters who commit crimes and threaten the security of the other citizens."

Whilst the official view is to improve the living conditions of Cemetery people which create an appropriate environment for communicable diseases, eviction and cemetery clearance will usually increase rather than decrease their health problems because of the very poor quality and location of the land on which they are forcibly "resettled".. If no alternative accommodation is provided for those displaced, they have to find space in other cheap areas and increase overcrowding .

Another justification for evictions is "redevelopment", to use the cleared land more intensively , and where developers can make very large profits redeveloping such sites, especially if they can avoid the cost of re-housing those evicted from these sites. As is evident from the other cases in Cairo, developers may make large profits by doing nothing more than clearing the site and holding the empty land for speculation. If settlements are judged to be "illegal", even if they have been there for many decades - this is a convenient excuse to bulldoze them without compensation.

Nevertheless the unwillingness or inability of government authorities ${ }^{2}$ to help increase the supply and reduce the cost of housing, and land for housing, and to ensure the provision of infrastructure and services, have left such poor groups with no option but to accept housing that is inadequate, overcrowded, insecure and poorly located. This is also attributed to the fact that government "low- 
cost" housing projects within the new Eastern desert Communities have delivered too little , since they often ended up in the hands of middle-class groups.

The government's commitment to clear the city central locations of "cemeteries" was confronted by the growing numbers of the urban poor tomb dwellers, with local authorities having neither the means nor the capacity to build residential areas to house them all., as a result of property speculation and the inability to raise the revenue needed to implement the plan. This plan was formulated devoid of any understanding of the realities of life for the poor on whom it was to be imposed. Selected sites for relocation (Cairo's New Eastern desert Settlements) were too far from the places of work and housing too costly for low-income households. The government did not consider the provision of services such as transport and water.

Ironically, the government machinery set up to respond to the housing problems of the poor has in fact been used against them, completely negating its purpose as illustrated by recent demolition plans and evictions. This is so despite an official policy which seeks to regularize (legalize) and upgrade Cemetery areas. Bulldozers have destroyed several long-standing Cemetery settlements, with the latter being considered legitimate since the state has failed in its responsibility to ensure that people can find adequate, legal shelter. The failure of the administration leaves the urban poor with no choice but to come up with its own solutions.

Since cemetery settlements lower the value of the surrounding land and its housing, and in a bid to "beautify" Cairo and to maintain or enhance land values, Bab El-Nasr Cemetery is cleared with little or no warning and its inhabitants evicted. More importantly, recent evictions are clearly not motivated by purely aesthetic factors, where financial gains are made from reclaiming illegally occupied land, much of which has increased substantially in value in the recent past. Once cleared of cemetery settlements characterized as a major obstacle in the path of "prosperity and development"., this land can be sold at great profit to commercial developers who will then construct "luxury" accommodation and shopping centres.

Furthermore the study survey within Bab El-Nasr Cemetery revealed the key role played by community leaders in organizing the struggle of poor Cemetery people for land on which they could build their homes, and then for basic infrastructure, services and, the right to manage their own homes. Such complex political struggles that people faced have included negotiations with government agencies, not only for shelter but also for the right to have their own democratic institutions in order to manage their settlements.

Therefore there is a need for continuing community resistance, as manifested in terms of the alliances developing between low-income cemetery people threatened with eviction and local NGOs and Community Development Intermediaries ${ }^{3}$. Such alliance can provide legal advice and help gain greater local, national support for the threatened communities who depend on casual labour for their work and who need to live in central locations to earn their livelihood. Such poor communities have no access to public low-cost housing finance institutions. Many city residents have no option other than to rely on Illegally occupying land or on acquiring Illegal subdivisions as the only way of obtaining land on which they can develop their shelter.

The study identified future expectations regarding local government's support for community initiatives to develop income-generating activities for relocated poor groups through mutual self-help; and through soft loans, subsidies and technical support to improve, rebuild or expand their new homes. 
There is a pertinent need to tackle problems in new settlements regarding inadequate provision for water, sanitation, drainage and the collection and disposal of garbage in partnership with different stakeholders from relocatees, community leaders, NGOs, local authorities to other agencies.

Nonetheless local NGOs with a strong commitment to participation, tend to keep costs down, and achieve cost recovery where possible, whilst avoiding the reinforcement of patronage and thus creating less dependency amongst relocated local communities

In conclusion therefore, the Cities of the Dead accommodate part of Cairo's poor who have creatively responded to their economic hardship and turned their temporary residences into permanent homes. The cemeteries have long been a place of residence for the guardians of tombs and the reciters of the Koran. To them have been added the poor and the deprived seeking refuge in and between the tombs. This informal community is now housed in contravention of building codes and zoning laws but they represent a solution to Cairo's housing crisis. Many of the inhabitants of the Cities of the Dead are second and third generation squatters, rural-urban migrants preserving in part the socio-cultural networks of their original villages. With many residents employed in the informal sector with its insecurity and poverty the cemeteries are considered as a potential breeding ground for Islamic fundamentalism.

Therefore there is a need for an overall strategy that sets the Cities of the Dead within the general framework of an economy unable to create sufficient jobs and to provide affordable housing for a large proportion of its population. Yet the dilemma of the Cities of the Dead cannot be resolved without a transformation of the average Cairene's attitude towards their squatter inhabitants. Whereas public opinion views the residents of the cemeteries negatively, often blaming them for their poverty and destitution, they should be given recognition for their positive response towards their homelessness and related problems. Both government and Cairo's wider society should cease to regard the Cities of the Dead as problem areas but should take note of the way these people have created a community through their apparently marginalised and illegal society. The squatter settlements of the Cities of the Dead represent a positive response by urban poor and by rural in-migrants to the deficiencies in social and economic services within Egyptian society. A more positive recognition of the Cities of the Dead by the wider Cairene society would serve to remove some of the stigma attached to their residents and could greatly improve the psychological outlook of the people involved.

Finally, both the uniqueness of the Cities of the Dead and their comparability with dynamic squatter settlements elsewhere should be appreciated before plans are implemented to move both cemeteries and their living residents out into new desert locations. Such a drastic relocation of tombs and resettlement of people threatens to meet likely failure given the authorities' apparent misunderstanding of the complexity of this multifaceted society.

\section{Acknowledgement}

This article is based on collaborative work with Keith Sutton at the School of Environment and Development, The University of Manchester

An earlier version of this paper was published with Keith Sutton in The Arab World Geographer, 5 (1): 1-21 (2002) under the title: Cairo's "Cities of the Dead": The Myths, Problems, and Future of a Unique Squatter Settlement. 


\section{References and Notes}

[1] El Kadi, G. La Cite des morts au Caire. Un abri pour les sans-abris, Maghreb-Machrek. 1990,127, 134-153.

[2] El Kadi, G. L'habitat dans la cite des morts au Caire, une forme d'habitat insalubre. In L 'Habitat Insalubre et Strategies d'Intervention. Actes du Seminaire Internationale de I'Agence Nationale de Lutte Centre L 'Habitat Insalubre. Meknes, Morocco, 1995, 125-150.

[3] General Organisation for Physical Planning (GOPP). The Transfer Plan of Environmentally Polluting Activities and the Relocation of Cemeteries within Cairo Governorate Residential Districts Priority Areas (in Arabic), Unpublished Report: Cairo, Egypt,1990.

[4] National Population Council (NPC). Awareness and Family Planning Practices among Residents of Cemeteries Hawch in Cairo Governorate (in Arabic), Unpublished Report: Cairo, Egypt, 1999.

[5] Sutton, K. and Fahmi, W. Cairo's "Cities of the Dead": The Myths, Problems, and Future of a Unique Squatter Settlement, The Arab World Geographer, 2002, 5 (1), 1-21.

[6] Shorter, F. Cairo's Leap Forward. People, Households and Dwelling Space, Cairo Papers in Social Science, 1989, 12(1), 3-42.

[7] Gad, M. Cemetery Residents in Cairo: a Historical Review and an Empirical Panorama (in Arabic); Dar Maged Publishing: Cairo, Egypt, 1992.

[8] El Kordy, M. Cemetery Residents in Cairo, a Social-Empirical Study. In Egyptian Yearbook of Sociology; El-Gawhary (ed.) ; Dar Al-Maaref, Cairo, Egypt, 1984,Volume 6, pp. 17-132.

[9] El Faramawy, M. A Social Study of Cemetery Residents (in Arabic); Faculty of Social Services, University of Helwan: Cairo, Egypt, 1992.

[10] Abu-Lughod, J. L. Cairo. 1001 Years of the City Victorious; Princeton University Press: Princeton, New Jersey, USA, 1971.

[11] Williams, C. Islamic Monuments in Cairo. A Practical Guide, $4^{\text {th }}$. Edition; American University in Cairo Press: Cairo, Egypt, 1993.

[12] Antoniou, J. Historic Cairo. A Walkthrough the Islamic City; American University in Cairo Press: Cairo, Egypt, 1998.

[13] Rodenbeck, M. Cairo, the City Victorious; Picador: London, UK, 1998.

[14] Goytisolo, J. The City of the Dead, Mediterraneans, 1991, 1, 8-32.

[15] Nedoroscik, J. A. The City of the Dead. A History of Cairo's Cemetery Communities; Bergin \& Garvey: Westport, Connecticut, USA, 1997.

[16] CAPMAS. General Census of Population, Housing and Buildings; Central Agency for Population, Mobilization and Statistics : Cairo Governorate, Egypt, 1986. 
[17] Turner, J. Housing Priorities, Settlement Patterns, and Urban Development in Modernizing Countries. Journal of the American Institute of Planners, 1968, 34, 354-363.

[18] Mangin, W. Latin American Squatter Settlements: A Problem and a Solution, Latin American Research Review, 1967, 2(3), 55-98.

[19] Potter, R.B. Urbanisation and Planning in the Third World: Spatial Perceptions and Public Participation; Croom Helm: London, UK, 1985.

[20] Edward, H. Conference donnee par Hoda Edward dans Ie cadre du 25eme anniversaire du GOPP (General Organisation for Physical Planning), Ie 27/04/98 au Centre Francais de Culture et de Cooperation, Lettre d 'Information de I 'Observatoire Urbain du Caire Contemporain, 1998, 48, 40-47.

[21] Madouef, A. De la ville au secteur, du centre au site: une lecture des projets d'amenagement de la ville ancienne du Caire, Les Cahiers d'URBAMA, 1995, 10, 44-58

(C) 2014 by the authors; licensee MDPI, Basel, Switzerland. This article is an open access article distributed under the terms and conditions of the Creative Commons Attribution license. 


\section{End Notes}

${ }^{1}$ Residents who wish to acquire a lease enter into the following process:

a. Application using the prescribed form along with supporting documentation including: area councilor's certificate verifying occupation of the plot; verification by witnesses; copy of Identity card; acceptance of responsibility In case of a missing statement regarding ownership of the plot; other documents such as electricity bills supporting a claim to continuous ownership of the plot.

c. Checking of plot size and land use.

d. Preparation of site plan and calculation of regularizable area on the prescribed form.

e. Removal of encroachment of the affected portion of the plot (if any) by the resident.

f. Payment of lease charges by applicant to a scheduled bank.

h. Issue of lease deed to applicant for affixing stamps

After this, the lease can be issued after more than four or five months. At every stage, the resident encounters corruption and harassment from state officials. The process generally takes 25-30 days which, for a low-income household, means lost income. In addition, between LE 400-1200 has to be paid in bribes. The Authority has recently reduced the steps involved in acquiring a lease and has undertaken a publicity campaign to spread Information on the process.

${ }^{2}$ Both Ministries of Housing and New Settlement, and of Social Affairs.

3 Such as the Coptic Evangelical Organization for Social Services (CEOSS), CARITAS (an international Catholic Charity), The Association for the Protection of the Environment (APE), The Association for the Development and Enhancement of Women (ADEW), The Centre for Development Services (CDS) 